\title{
Trauma Patient with Fat Embolism Detected on Computed Tomography
}

\section{Politraumatizado com Embolia Gorda Detectada em Tomografia Computorizada}

Isabel SOUSA $\triangle^{1}$, João JANEIRO ${ }^{1}$, Paula CAMPOS ${ }^{1}$, Isabel TÁVORA ${ }^{1}$
Acta Med Port 2017 Jan;30(1):73-76 : http://dx.doi.org/10.20344/amp.7355

\section{ABSTRACT}

Fat embolism is frequent following fractures of long bones, however the development of the clinical syndrome of fat embolism (characterized by progressive respiratory distress, mental status depression and petechial rash) is rare, but relevant because of its potential severity. We report a case of a trauma patient with multiple fractures of the right lower limb in whom an emergency computed tomography scan showed fat emboli within the lumen of the homolateral common femoral vein. The imaging detection of macroscopic fat emboli should alert the clinician to the potential for subsequent fat embolism syndrome.

Keywords: Embolism, Fat/diagnostic imaging; Fractures, Bone; Tomography, X-Ray Computed

\section{RESUMO}

A embolia gorda é frequente no contexto de fracturas de ossos longos, contudo o desenvolvimento da síndrome clínica da embolia gorda (caracterizada por dificuldade respiratória progressiva, depressão do estado de consciência e rash petequial) constitui uma ocorrência rara, embora relevante pela sua gravidade. Apresentamos o caso de um politraumatizado com fraturas múltiplas do membro inferior direito a quem foi detetada, em tomografia computorizada de urgência, a presença de êmbolos de gordura no lúmen da veia femoral comum homolateral. A visualização de êmbolos macroscópicos de gordura através de métodos de imagem deverá alertar o clínico para a possibilidade de desenvolvimento da síndrome da embolia gorda.

Palavras-chave: Embolia Gordurosa/diagnóstico por imagem; Fracturas Ósseas; Tomografia Computadorizada

\section{INTRODUCTION}

Fat embolism is a frequent occurrence in trauma patients (90\%), although the clinical syndrome of fat embolism is far less common, developing in about $3 \%$ to $4 \%$ of patients with long bones fractures. ${ }^{1}$

The detection of macroscopic fat emboli in the systemic veins or pulmonary arteries through computed tomography (CT) is even rarer with only a few cases published, ${ }^{2-8}$ to the authors' knowledge.

In this context, we present a case of detection of fat emboli within the lumen of the right common femoral vein on CT in a trauma patient, following multiple bone fractures of this limb.

\section{CLINICAL CASE}

A 22-year-old male was admitted to the emergency department of our hospital following a motorcycle accident with collision damage to his right hemibody.

Upon arrival to the hospital, the patient had a Glasgow Coma Scale score of 15 , was hypotensive and presented with a diaphyseal fracture of the femur, distal epiphyseal fracture of the tibia and open fractures of the right foot, confirmed with the plain films, in a primary evaluation.

The limb was immobilized and after haemodynamic stabilization, an angio-CT of the lower limbs was requested to evaluate the integrity of the arterial axis.

The CT angiogram clearly depicted the right femoral shaft fracture with complete displacement between the distal and proximal fragments (Fig. 1), the distal tibial fracture and the multiple fractures and luxations of the foot bones and also showed signs of extravasation of contrast representing acute bleeding from branches of the deep femoral artery (Fig.s 1 and 2) and two fat density endoluminal defects within the common femoral vein in keeping with fat emboli (Fig. 3).

An external fixation procedure to stabilize the femoral fracture and reconstruction of the right foot with Kirschner wires were performed in a few hours after arrival. Conservative management with clinical surveillance was decided for both the above mentioned vascular complications.

On the first day of post-operative period the patient developed a compartment syndrome of the right thigh and an emergency fasciotomy was undertaken.

A follow-up CT angiogram of the lower limbs performed two days after admission showed enlargement and heterogeneity of the soft tissue planes (in part due to haematic infiltration), with patency of the main arterial axis and no signs of active arterial haemorrhage, the right common femoral vein was homogeneously opacified, with complete resolution of the endoluminal defects (Fig. 4). The patient did not present any signs of respiratory distress or mental status impairment. Review of the fasciotomy incisions was performed.

As a consequence of rhabdomyolysis, an acute kidney failure developed and was treated with vigorous hydratation.

During the five-day admittance in the intensive care

1. Serviço de Imagiologia Geral. Hospital de Santa Maria. Centro Hospitalar Lisboa Norte. Lisboa. Portugal.

$\triangle$ Autor correspondente: Isabel Sousa. isabelrsousa@gmail.com

Recebido: 31 de dezembro de 2015 - Aceite: 26 de Julho de 2016 | Copyright @ Ordem dos Médicos 2017 


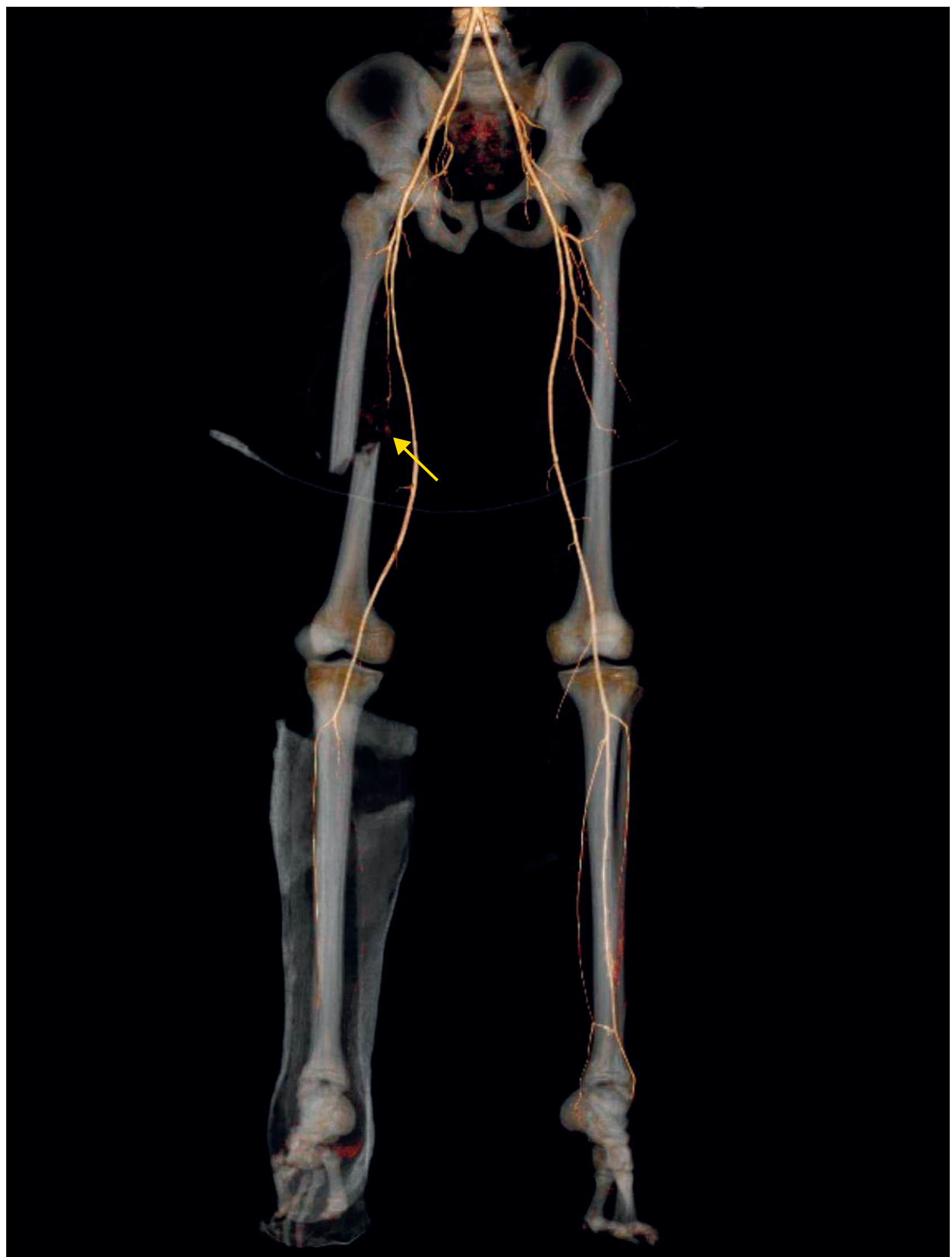

Figure 1 - CT angiogram 3D reformat showing the diaphyseal fracture of the right femur and in its proximity a mild extraluminal arterial blush (arrow) originating from branches of the right deep femoral artery consistent with active bleeding (finding also depicted in Fig. 2) is visualized. 

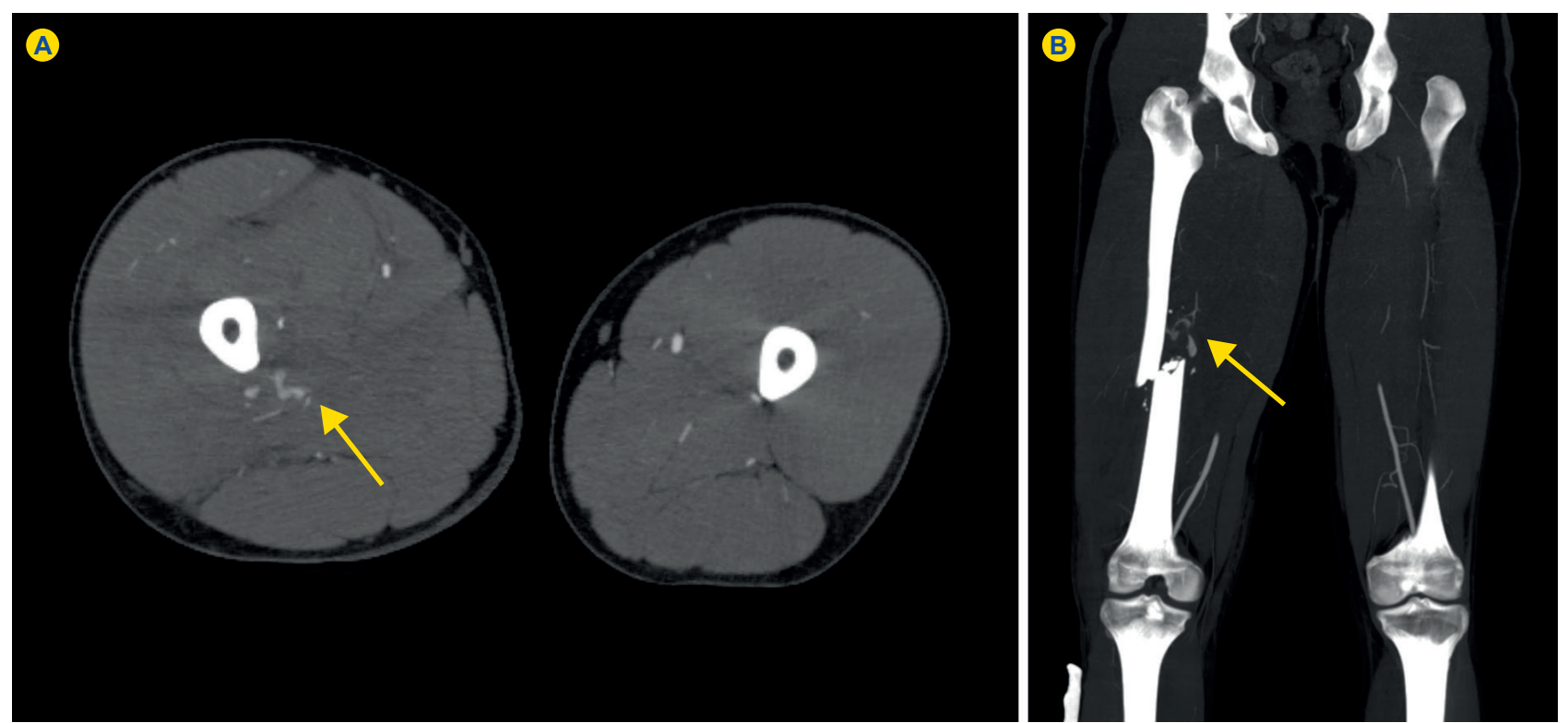

Figure 2 - MIP reformat in axial (A) and coronal (B) planes of the lower limb CT angiogram depicting the site of active extravasation of contrast (haemorrhage) from branches of the right deep femoral artery (arrow). An asymmetry of volume between the thighs due to oedema and haematic infiltration of the muscle and intermuscular planes of the right thigh is also noted.

unit, there were no signs of the clinical syndrome of fat embolism. When stabilized, the patient was transferred to the orthopaedic ward to proceed with his treatment.

\section{DISCUSSION}

A minority of patients with fat embolism becomes symptomatic and develops the associated clinical syndrome. Although multisystemic, the classical triad consists of a deteriorating mental status, progressive respiratory failure and petechial rash, usually manifesting within 24 - 48 hours of the primary event.

Several clinical diagnostic criteria and scores have been proposed (Gurd and Wilson criteria, Fat Embolism Index by Schonfeld and Lindeque criteria). ${ }^{9}$

The majority of cases of fat embolism syndrome are described in association with a traumatic event such as a bone fracture or following orthopaedic procedures with intramedullary fixation devices.

Two hypotheses were proposed to explain the pathogenesis of the syndrome in the early $20^{\text {th }}$ century. The mechanical theory (suggested by Gauss) postulates that fat particles gain access to the circulation via the ruptured veins at the site of the adipose tissue damage. ${ }^{10}$ These droplets would then reach the pulmonary circulation, however the route allowing for the access to the systemic vessels is not so clear, with a few mechanisms being pointed as possible: passage through a patent foramen ovale, transfer at the level of the pulmonary capillaries or via a intrapulmonic pulmonary-bronchial shunt. ${ }^{9}$ The biochemical theory established by Lehman proposed that plasma mediators could mobilize lipids from body stores. ${ }^{10}$ These fatty acids would be directly toxic to the lung. ${ }^{3}$

The demonstration of macroscopic fat emboli through cross-sectional imaging, as in our case, is infrequent, with a few case reports of fat emboli in the pulmonary arterial tree $e^{4,5,7}$ and in the femoral veins and/or inferior vena cava. $2,3,6,8$

The detection of fat emboli in the cerebral arterial circulation has also been reported as the 'hypodense artery sign'. ${ }^{11}$

The lung parenchymal findings include the presence of ground-glass opacities, nodules, consolidation and
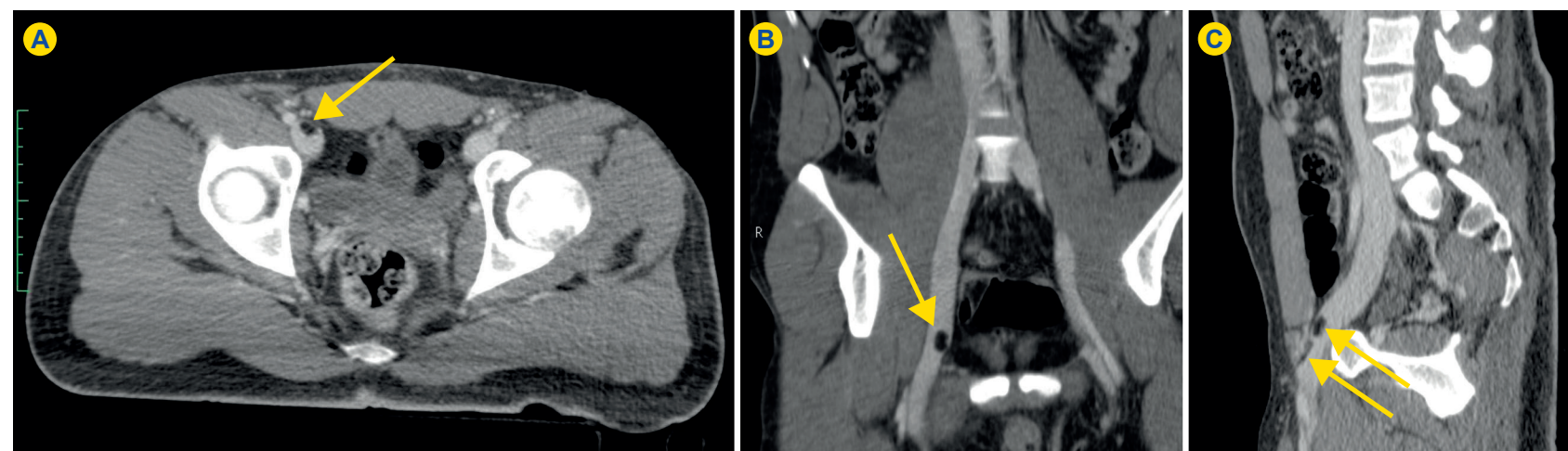

Figure 3 - CT of the pelvis after intravenous contrast in venous phase (axial plane image in A, coronal oblique reformat in B and sagital oblique reformat in C) depicting two fat density defects (arrows) in the lumen of the right common femoral vein in keeping with fat emboli. 

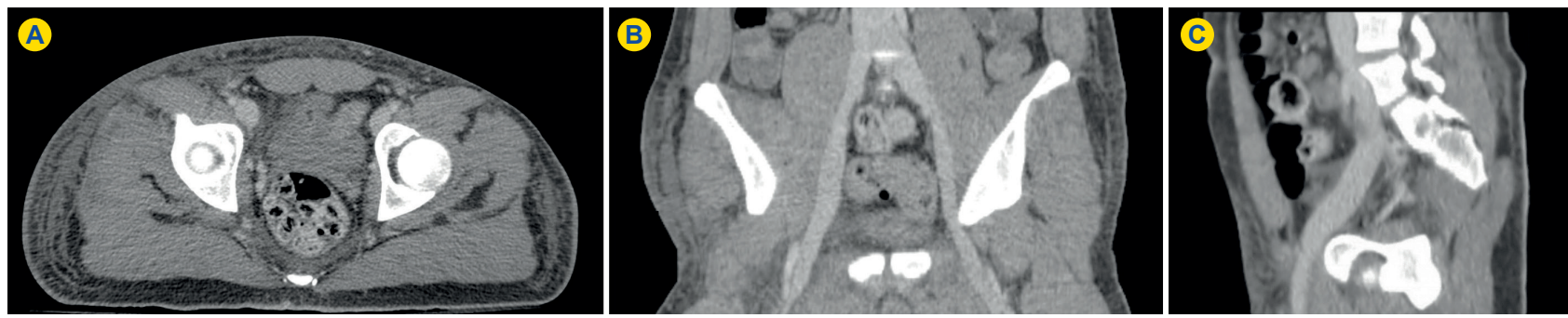

Figure 4 - CT of the pelvis after intravenous contrast in venous phase (same planes as in Fig. 3) showing normally opacified right common femoral vein, without any endoluminal defects.

thickening of the interlobular septa. ${ }^{12}$

A "starfield" pattern in diffusion-weighted brain magnetic resonance representing acute cerebral microinfarcts is described in cerebral fat embolism. ${ }^{13}$

In our case, after detection of the macroscopic fat emboli in the common femoral vein and evaluation by vascular surgery, it was decided to manage the patient conservatively, as he was asymptomatic at presentation and the initial priority was to stabilize the multiple fractures. Active clinical vigilance was employed in our case, with no evidence of subsequent development of the fat embolism syndrome.

Although there are reports of surgical intervention with venotomy for removal of the fat embolus and temporary placement of inferior vena cava filters, ${ }^{6,8}$ its value is questionable. In autopsy studies endoluminal fat can be seen on lung vessels in more than $90 \%$ of patients with skeletal trauma; however, the clinical picture of fat embolism syndrome does not occur in all patients in whom intravascular fat is demonstrated. ${ }^{9}$

\section{REFERENCES}

1. Levy D. The fat embolism syndrome: a review. Clin Orthop Relat Res. 1990;261:281-6.

2. Liu P, Armstrong $P$, Skippen P. Post-traumatic fat embolism in the inferior vena cava. Can Assoc Radiol J. 1990;41:303-4

3. Harris A, Torreggiani W, Lyburn I, Zwirewich C, Ho S, Munk P. CT and sonography of traumatic fat embolism in the common femoral vein. Am J Roentgenol. 2000;175:1741-2.

4. Ravenel J, Heyneman L, McAdams H. Computed tomography diagnosis of macroscopic pulmonary fat embolism. J Thorac Imaging. 2002;17:154-6.

5. Nucifora G, Hysko F, Vit A, Vasciaveo A. Pulmonary fat embolism: common and unusual computed tomography findings. J Comput Assist Tomogr. 2007;31:806-7

6. Rosón N, Berrocal L, Garriga V, Garcia D, Pruna X, Garro P, et al. Fat embolism of the common and superficial femoral vein: US and CT diagnose, imaging follow-up and histopathologic correlation after surgical venotomy. Eurorad. 2008. [accessed 2015 Nov 18]. Available from: http://www.eurorad.org/case.php?id=6480.

7. Huang B, Monu J, Wandtke J. Pulmonary fat embolism after pelvic and
The mainstay of the treatment of the fat embolism syndrome is supportive with no reduction in mortality or morbidity demonstrated with heparin, dextran or corticosteroids, although the last may have positive effects in a preventive approach. ${ }^{14}$

Mortality has decreased to less than $10 \%$ of the cases with the advances in supportive care..$^{15}$

In conclusion, fat embolism is a frequent phenomenon in association with traumatic bone injury and in the majority of the cases is asymptomatic. Detection of macroscopic fat emboli through imaging should alert the clinician to the possibility of developing the clinical syndrome.

\section{CONFLICTS OF INTEREST}

The authors declare that there are no conflicts of interest.

\section{FUNDING SOURCES}

No subsidies or grants contributed to this work.

long bone fractures in a trauma patient. Emerg Radiol. 2009;16:407-9.

8. Vasconcelos V, Andriotti C, Reicher M, Amorim J, Miranda Junior F. Imaging and histological findings of fat embolism in the vena cava. Trauma. 2015;17:295-8.

9. Akhtar S. Fat embolism. Anesthesiol Clin. 2009;27:533-50.

10. Talbot M, Schemtsch E. Fat embolism syndrome: history, definition, epidemiology. Int J Care Injured. 2006;37:S3-7.

11. Lee T, Bartlett E, Fox A, Symons S. The hypodense artery sign. Am J Neuroradiol. 2005;26:2027-9.

12. Arakawa H, Kurihara $\mathrm{Y}$, Nakajima Y. Pulmonary fat embolism: CT findings in six patients. J Comput Assist Tomogr. 2000;24:24-9.

13. Parizel P, Demey $H$, Veeckmans $G$, Verstreken F, Cras $P$, Jorens $P$, et al. Early diagnosis of cerebral fat embolism dyndrome by diffusionweighted MRI (starfield pattern). Stroke. 2001;32:2942-4.

14. Habashi N, Andrews P, Scalea T. Therapeutic aspects of fat embolism syndrome. Injury. 2006;37:S68-73.

15. Kosova E, Bergmark B, Piazza G. Fat embolism syndrome. Circulation. 2015;131:317-20. 